\title{
Comparative study on pre and post point of lay performance of noiler and two commercial pullets
}

${ }^{1}$ Mosobalaje, M. A. and ${ }^{2}$ Adedoyin, A. A.

${ }^{\prime}$ Department of Animal Health and Production, Oyo State College of Agriculture and Technology, Igboora,

${ }^{2}$ Department of Agricultural Education, Animal Nutrition and Biotechnology Unit,

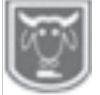

Oyo State College of Education Lanlante, Oyo State, Nigeria.

Corresponding author:*mosobahs@yahoo.com; 08034780805

Abstract

The use of Noiler strain as commercial laying chicken is gradually becoming popular in Nigeria, however, performance of chicken is affected by strain. The pre and post point of lay characteristics of three strains of commercial pullets: Isa Brown, Nera Black and Noiler were studied using 300 day-old chicks (100 chicks per strain) purchased from local hatcheries. The birds were raised on commercial feed for ten weeks before the commencement of the study. The experimental birds were allotted into three treatments. There were four replicates per treatment and each replicate contained 25 birds. The 12 replicates were arranged in a complete randomized design. For the post point of lay study, 15 birds were randomly selected from each replicate. Commercial grower mash was fed to the three strains before the birds attained point of lay, however, layer mash was used when the birds became layers. The parameters collected for pre lay characteristics were initial weight, feed intake, body weight at 18th week, weight gain, egg weight at 24 weeks, mortality, age at first egg, weight of the first egg, age at $20 \%$ Hen Day Production (HDP). The post point of lay study lasted thirty-four weeks. The parameters considered were HDP at 24th week, average egg production, egg weight and final weight. The values obtained for feed intake, weight at $18^{\text {th }}$ week, weight gain and age at $20 \%$ HDP were significantly $(P<0.05)$ different. Noiler had values $85.86 \mathrm{~g} / \mathrm{bird} /$ day, $2189.23 \mathrm{~g} / \mathrm{bird}, 12.52 \mathrm{~g} / \mathrm{bird} /$ day and 160.75 days, respectively and were significantly $(p<0.05)$ higher than the values obtained for the other two strains. However, Isa brown and Nera black had similar $(p>0.05)$ values for these parameters $(63.73$ and $61.09 \mathrm{~g} / \mathrm{bird} /$ day; 1493.33 and $1531.25 \mathrm{~g} / \mathrm{bird;} 8.95$ and $8.84 \mathrm{~g} / \mathrm{bird} /$ day; 155.00 and 153.75days, respectively). Weight offirst egg, mortality, age at first egg and weight of eggs at 24 week old were not significantly affected $(p>0.05)$ by strains, however, Noiler growing pullets recorded the lowest values for these parameters. The ranges were $40.43-44.43 g$; $0.00-1.00 \%$; $136.25-145.00 d$ and $52.25-57.11 \mathrm{~g}$, respectively. Results of post point of lay revealed that feed intake, final weight and egg weight were affected by the strains. Noiler had highest values $(132.24 \mathrm{~g} /$ day/bird, $2.76 \mathrm{~kg} / \mathrm{bird}$ and $63.80 \mathrm{~g}$, respectively) which were significantly higher $(p<0.05)$ than values for Nera black $(129.82 \mathrm{~g} / \mathrm{day} / \mathrm{bird}, 2.06 \mathrm{~kg} / \mathrm{bird}$ and $59.72 \mathrm{~g}$, respectively) and Isa brown $(128.40 \mathrm{~g} / \mathrm{day} / \mathrm{bird}, 1.93 \mathrm{~kg} / \mathrm{bird}$ and $58.03 \mathrm{~g}$, respectively). Egg productions were also significantly affected $(p<0.05)$ and favoured Isa brown strain. Conclusively, this study showed that growth and production performance of chicken are influenced by strains; Noiler chicken showed better growth performance, however, Is a brown had the best egg production performance.

Keywords: Egg production, growth performance, noiler, and strains 
Point of lay performance of three strains of chicken

\section{Étude comparative sur le point de vue prédéfini des performances posées de la ponte de noiler et de deux poulettes commerciales}

\section{Résumé}

L'utilisation de la souche de noiler en tant que poulet ponte commerciale devient progressivement populaire au Nigéria, cependant, la performance de poulet est affectée par la souche. Les caractéristiques postales de trois souches de poulettes commerciales: Isa Brown, Naera Noir et Noiler ont été étudiées avec des poussins de 300 jours (100 poussins par souche) achetés dans des écloseries locales. Les oiseaux ont été élevés sur des aliments commerciaux pendant dix semaines avant le début de l'étude. Les oiseaux expérimentaux ont été attribués en trois traitements. Il y avait quatre répliquant par traitement et chaque réplique contenait 25 oiseaux. Les 12 répliquant ont été disposés dans une conception randomisée complète. Pour le point de post de l'étude laïque, 15 oiseaux ont été choisis de manière aléatoire à partir de chaque manche de producteurs de répliqué. De la purée commerciale de producteurs a été donnée aux trois souches avant que les oiseaux n'atteignent le point de ponte, cependant, une purée de poules pondeuses a été utilisée lorsque les poules sont devenues pondeuses. Les paramètres recueillis pour des caractéristiques pré-posées ont été un poids initial, une consommation alimentaire, un poids corporel à la 18 ème semaine, un gain de poids, un poids d'œufs à 24 semaines, la mortalité, l'âge au premier œwuf, le poids du premier œuf, l'âge à 20\% de production de la journée de poule (PJP). Le point postal de l'étude lä̈que a duré trente-quatre semaines. Les paramètres considérés sont considérés en PJP à 24ème de semaine, la production moyenne des æufs, le poids des œufs et le poids final. Les valeurs obtenues pour l'apport alimentaire, le poids à la 18 ème semaine, le gain de poids et l'âge à 20\% de PJP étaient de manière significative (p $<0,05$ ) différente. Noiler avait des valeurs $85.86 \mathrm{~g} / \mathrm{oiseau} / \mathrm{jour}, 2189,23 \mathrm{~g} / \mathrm{oiseau}, 12.52 \mathrm{~g} /$ oiseau / jour et 160,75 jours, respectivement et étaient significativement $(p<0,05)$ supérieur aux valeurs obtenues pour les deux autres souches. Cependant, Isa Brown et Nera Black avaient des valeurs similaires ( $p>0,05)$ pour ces paramètres $(63,73$ et 61,09 g/oiseau / jour; 1493,33 et 1531,25g / oiseau; 8,95 et 8,84 g / oiseau / jour; 155,00 et 153,75 jours, respectivement). Le poids du premier œuf, la mortalité, l'âge au premier œuf et le poids d'œufs à 24 semaines n'était pas significativement affecté ( $p>0,05)$ par des souches, cependant, les poulettes de croissance noiler ont enregistré les valeurs les plus basses pour ces paramètres. Les gammes étaient de 40,43 - 44,43g; 0,00 - 1,00\%; 136.25 - 145.00d et 52,25 - 57.11g, respectivement. Les résultats du post point de ponte ont révélé que la prise alimentaire, le poids final et le poids des aufs étaient affectés par les souches. Noiler avait des valeurs les plus élevées (132,24 g / jour / oiseau, 2,76 kg / oiseau et $63.80 \mathrm{~g}$, respectivement) qui étaient significativement plus élevées $(p<0,05)$ que des valeurs pour Nera noir (129,82 g/jour / oiseau, 2,06 kg / oiseau et 59,72 g, respectivement) et Isa Brown (128,40 g/jour / oiseau, 1,93 kg / oiseau et 58,03g, respectivement). Les productions d'œufs ont également été significativement affectées $(p<0,05)$ et favorisent la souche Isa Brown. En conclusion, cette étude a montré que la croissance et la performance de la production de poulet sont influencées par des souches; Le poulet de noiler a révélé une meilleure performance de croissance, cependant, Isa Brown avait la meilleure performance de la production d'oufs.

Mots-clés: Production d'œufs, Performance de croissance, noiler et Souches 


\section{Mosobalaje and Adedoyin}

\section{Introduction}

Genetic variation in egg production between breeds, strains and lines has been reported (Hocking et al., 2003). There is strong evidence that there are genetic differences in growth rate between strains or breeds of chickens (Deeb and Lamont, 2002). Point of lay is in fact a very vague description of pullets that are in the process of developing to an age where, in the near future, they will become mature and therefore producing eggs (Leeson and Summer, 2005; Shingleton, 2004; Oluyemi and Robort, 2000). The average age for chickens to come into normal lay is around 22 - 24 weeks, but this does depend on the time of year and, in some cases, how they have been reared and especially nutrition and the strain (Bright and Joret, 2012). Point of lay birds is the birds on $20 \%$ Hen Day Production (Oluyemi and Robert, 2000), however, the chances of buying a pullet that will produce eggs within the first few days after purchase is highly unlikely (Mitchell and Kettlewell, 2004). The sale of the many varieties of commercial poultry breeds has increased on a massive scale. Birds are sold as 'point of lay' - but are they really described correctly? Or should the buyer be given an exact age to give them an idea as to when the bird will in fact produce its first egg? (FAWC, 2007). However, there are many features that distinguished good growers and the poor ones (Leeson and Summer, 2005). Many factors are responsible for the attainment of point of lay at prescribed age. These include housing, diseases, environmental conditions, nutrition especially energy content of the feed (Leeson and Summer, 2005) and the breed (Bright and Joret, 2012). Significant differences in body weight due to differences in strains has been reported with the black and brown plumage layer strains varying in their productive capability and livability in the hot climates. Olawumi (2006) reported that parents of black layer strain had lower mortality rate but are more adaptable to hot weather than parents of brown layer strain. The production potential of a good layer strain is better assessed based on the number and size of eggs produced during its lifetime and its final weight as spent-hen. Although management and feeding practices are the key determining factors of egg production, the breed of laying hen affects egg production. The rate of adaptation and quality of egg production of different exotic breeds of hen vary when exposed to a variety of climate and environments. The black and brown plumage layer strains are commonly raised for egg production in Nigeria (Olawumi et al., 2006). The brown layers are good converters of feeds to eggs, consumed less than black layers and yet produced more eggs than the latter as reported by Olawumi et al. (2006). The Kuroiler is a hybrid breed of chicken developed in India. Kuroilers are derived from crossing either coloured broiler males with Rhode Island Red females, or, White Leghorn males crossed with female Rhode Island Reds (Sandilands and Hockin, 2012). In chickens, growth rate can be improved through crossing different breeds together to utilize heterosis in their progenies. Kuroilers, a dual-purpose breed producing meat and eggs, can live on a diet of kitchen and agricultural waste, and produce around 150 eggs per year. Due to its unique genetic features, the Kuroiler is resistant to diseases. The Kuroiler chick is a potential bio-converter of low cost agricultural, household and natural wastes abundant in villages into human protein food and substantial incomes for rural household (www.kuroilerchicken.com).

\section{Materials and methods}

The experiment was carried out at Oyo State College of Agriculture and Technology poultry farm. The birds were purchased from two different hatcheries at day old and raised to grower stage on commercial feed. 


\section{Point of lay performance of three strains of chicken}

Two of the three strains were purchased from the same hatchery and one strain from another hatchery. At 10th week, the growers were randomly allotted to three treatments with each strain representing a treatment. There were four replicates per treatment with 25 birds each. A complete randomized design was adopted for the experiment. The following parameters were collected and/or calculated; Initial body weight, feed intake, weight at 18th week, weight gain, egg weight at 24 weeks, mortality, age at first egg, weight of the first egg, Hen Day Production (HDP) at 24th week, age at 20\% HDP. For the post point of lay study, fifteen birds were randomly selected form each replicate. Each of the strains represents the treatment, thus there were three treatments with four replicates of fifteen birds each. The birds were fed commercial layer feed for thirty-four weeks. The parameters considered were egg production, egg weight, final weight. Data obtained were subjected to analysis of variance (ANOVA) and where differences exist between means, Duncan Multiple Range Test was used to separate the means at $5 \%$ probability level.

\section{Results and discussion \\ Pre point of lay characteristics}

Results of pre lay characteristics of Noiler point of lay as compared with Isa brown and Nera black are presented in Table 1. The values obtained for feed intake, weight at $18^{\text {th }}$ week, weight gain and age at $20 \%$ henday production were significantly $(\mathrm{P}<0.05)$ different, and Noiler had the values which were significantly $(p<0.05)$ higher than the values obtained for the other two strains. However, Isa brown and Nera black had similar $(p>0.05)$ values for these parameters. Noiler recorded the highest feed intake $(85.86 \mathrm{~g} / \mathrm{bird} /$ day $)$ that was significantly higher than values recorded for Isa brown and Nera black. Nera Black had $63.73 \mathrm{~g} / \mathrm{bird} /$ day and similar $(\mathrm{p}>0.05)$ to Isa brown that recorded the least value
(61.09 g/bird/day). Noiler recorded the significantly higher $(\mathrm{p}<0.05)$ value for weight at $18^{\text {th }}$ week $(2189.23 \mathrm{~g} / \mathrm{bird} /$ day $)$, followed by Nera black that recorded $1531.25 \mathrm{~g} / \mathrm{bird} /$ day while Isa brown recorded the lowest value (1493.33g/bird/day). Similarly, Noiler had significantly higher $(p<0.05)$ value of weight gain $(12.52 \mathrm{~g} / \mathrm{bird} /$ day $)$, followed by Nera black $(8.95 \mathrm{~g} / \mathrm{bird} /$ day $)$ and Isa brown that had the least value $(8.84 \mathrm{~g} / \mathrm{bird} /$ day $)$. For age at $20 \%$ hen-day production, Noiler recorded the highest value (156.75days), Isa brown was 146days, while Nera black was 143.75 days. However, they were not significantly different when subjected to statistical analysis. Weight of first egg for Isa brown was the highest value (43.43g), while Nera black was $41.52 \mathrm{~g}$ and Noiler recorded the lowest value of $40.43 \mathrm{~g}$. These values were not significantly $(p>0.05)$ different. Nera black recorded the highest value $(57.11 \mathrm{~g})$ of egg weight at 24weeks followed by Isa brown (56.43g), while Noiler recorded the lowest value $(52.26 \mathrm{~g})$ and all these values were not significantly ( $p>0.05$ ) different. The result of mortality was not significantly $(\mathrm{p}>0.05)$ different, Isa brown and Noiler had the same value $(1.00 \%)$ while Nera black had the least value. The result of initial weight showed that Noiler had significant higher value and the other two strains had similar values. Noiler, being bred from heavy breed (Sandilands and Hockin, 2012) was heavier at $18^{\text {th }}$ week than breed from light breed (Oluyemi and Robert, 2000). The initial weight of Isa brown and Nera black strains confirmed Olawumi (2007) and Ayorinde et al. (1999) who presented the weight of 1449.6+17.24g in Nera black and $1445.45 \mathrm{~g}$ in 20 weeks Isa brown pullets. Meanwhile, weight attained by Noiler at 18 weeks confirmed that it is a heavy breed (Sandilands and Hockin, 2012) The mean feed intake of Noiler was significantly higher than those of Nera black and Isa 


\section{Mosobalaje and Adedoyin}

brown. The mean feed intake per day of all the three strains confirmed the statement of Rose (1997) that birds eat 5\% of their body weight per day. However, this finding disagreed with Leeson and Summer (1981) that suggested that energy intake of the growing pullet is the limiting factor to growth rate, since regardless of diet specification, pullets seem to consume similar quantities of energy. Thus genetic make-up is another factor responsible for feed intake of growing pullets. The feed conversion ratio of Isa brown and Nera black were higher to that of Noiler despite the higher feed consumption of Noiler. Noiler pullet strain was the most efficient in feed conversion to body weight, a quality attributed to heavy breed of domestic fowl (Oluyemi and Robert, 2000). FCR values recorded for Isa brown and Nera black were higher than values reported by Imouokhome (2012).

Table 1: Pre lay characteristics of three strains of pullet growers

\begin{tabular}{|c|c|c|c|c|}
\hline Parameters & $\begin{array}{l}\text { Treatment } 1 \\
\text { Isa brown }\end{array}$ & $\begin{array}{l}\text { Treatment } 2 \\
\text { Nera black }\end{array}$ & $\begin{array}{l}\text { Treatment } 3 \\
\text { Noiler }\end{array}$ & SEM \\
\hline $\begin{array}{l}\text { Average feed intake }(10 \\
\text { (g/bird/day) }\end{array}$ & $61.09^{\mathrm{b}}$ & $63.73^{\mathrm{b}}$ & $85.86^{\mathrm{a}}$ & 1.86 \\
\hline Weight at $18^{\text {th }}$ wks (g/bird) & $1493.33^{b}$ & $1531.25^{b}$ & $2189.25^{\mathrm{a}}$ & 48.58 \\
\hline Feed Conversion Ratio & 7.10 & 7.23 & 6.87 & 0.60 \\
\hline Weight gain (g/bird/day) & $8.84^{\mathrm{b}}$ & $8.95^{\mathrm{b}}$ & $12.52^{\mathrm{a}}$ & 0.71 \\
\hline Mortality $(\%)$ & 1.00 & 0.00 & 1.00 & 1.16 \\
\hline Age at first egg (days) & 144.25 & 145.00 & 136.25 & 3.68 \\
\hline Weight of first egg $(\mathrm{g})$ & 43.43 & 41.52 & 40.43 & 3.23 \\
\hline Age at $20 \%$ hen-day production $(\%)$ & $155.00^{\mathrm{b}}$ & $153.75^{\mathrm{b}}$ & $160.75^{\mathrm{a}}$ & 1.92 \\
\hline
\end{tabular}

The result of the mortality showed that the survival rate of the three strains were similar. Olawumi, and Dudusola (2011) reported that parent of black layer strain had lower mortality rate and more adaptable to the hot weather than parents of brown layer strain. It was indicated in this study that regardless of strain, a positive association between body weight and sexually maturity was established as Noiler with the highest body weight at 18th week laid the first egg. However, result of egg weight of the first egg disagreed with finding of other workers that first egg was progressively heavier with delayed maturity (Hockings, 1987), as Isa brown that started before Nera black recorded heavier egg. This however confirmed the fact that Isa brown are known for bigger eggs (Kassandra, 2015). Noiler that recorded the first egg however attained $20 \% \mathrm{HDP}$ at age significantly higher than age of Nera and Isa. Egg production and egg weight at 24 weeks of Noiler strain were also low.

\section{Post point of lay characteristics}

Results of post point of lay characteristics of the three strains showed that hen day production was significantly affected $(p<0.05)$, Isa brown strain had the highest value $(80.57 \%)$ followed by Nera black $(72.45 \%)$ while Noiler strain had the least egg production with $(60.47 \%)$. Isa brown recorded significantly highest value $(61.31 \%)$ for hen day production at 24 weeks, however, similar $(p>0.05)$ to value recorded by Nera black (55.38\%), while Noiler recorded the least value $(39.76 \%)$ and significantly $(\mathrm{p}>0.05)$ lower than Isa and Nera strains. All the values were significantly different $(\mathrm{p}<0.05)$ across the treatments. Hocking et al., 2003 reported genetic variation in egg production between breeds, strains and lines. The result confirmed the findings of Yakubu et al., 2008 which reported that egg production differed among strains of layers. In contrast, 


\section{Point of lay performance of three strains of chicken}

however, Hossain (1992) reported no significant strain effect in egg production. These poor post lay characteristics portrayed Noiler as a poor egg layers compared to Isa brown and Nera black.

Table 2: Post point of lay characteristics of the three strains

\begin{tabular}{lllll}
\hline Parameters & $\begin{array}{l}\text { Treatment1 } \\
\text { Nera black }\end{array}$ & $\begin{array}{l}\text { Treatment 2 } \\
\text { Isa brown }\end{array}$ & $\begin{array}{l}\text { Treatment 3 } \\
\text { Noiler }\end{array}$ & SEM \\
\hline Hen-day production at 24wks (\%) & $61.31^{\mathrm{a}}$ & $55.38^{\mathrm{a}}$ & $39.76^{\mathrm{b}}$ & 3.01 \\
Egg weight at 24 wks (g) & 56.43 & 57.11 & 52.26 & 0.95 \\
Age when egg production peaked (day) & 196 & 202 & 206 & 1.01 \\
Hen day Production (\%) & $80.57^{\mathrm{a}}$ & $72.45^{\mathrm{b}}$ & $60.47^{\mathrm{c}}$ & 2.51 \\
Feed intake (g/day/bird) & $128.40^{\mathrm{b}}$ & $129.82^{\mathrm{b}}$ & $132.24^{\mathrm{a}}$ & 2.68 \\
Final weight (g/bird) & $1.93^{\mathrm{b}}$ & $2.06^{\mathrm{b}}$ & $2.76^{\mathrm{a}}$ & 0.06 \\
Egg weight (g) & $58.03^{\mathrm{b}}$ & $59.72^{\mathrm{b}}$ & $63.80^{\mathrm{a}}$ & 1.92 \\
Mortality (\%) & 5.00 & 3.33 & 3.33 & 3.16 \\
\hline
\end{tabular}

abc: Means with different subscripts are significantly different $(\mathrm{p}<0.05>$

The feed intake, final weight and egg weight were affected by strain. Noiler had highest values $(132.24 \mathrm{~g} / \mathrm{day} / \mathrm{bird}$, $2.76 \mathrm{~kg} / \mathrm{bird}$ and $63.80 \mathrm{~g}$, respectively) which were significantly higher $(\mathrm{p}<0.05)$ than Nera black (129.82g/day/bird, $2.06 \mathrm{~kg} / \mathrm{bird}$ and $59.72 \mathrm{~g}$, respectively) and Isa brown $(128.40 \mathrm{~g} /$ day/bird, $1.93 \mathrm{~kg} /$ bird and $58.03 \mathrm{~g}$, respectively). The values obtained for Nera black and Isa brown were similar $(p>0.05)$. Laying hens in egg producing farms are usually of small body frame and body weight compared to broilers. Egg producing chicken breeds have been bred and raised for maximum egg production (up to 300 eggs per year) rather than high meat yield (Beutler, 2007). Feed intake is a function of the body weight (Rose, 1997) hence Noiler recorded higher value of feed intake compared to Isa brown and near black.

\section{Conclusion}

The positive significant pre lay characteristics of Noiler compared to Isa brown and Nera black were however not the same at post lay period as Noiler recorded lower post lay characteristics. These poor post lay characteristics portrayed Noiler as a poor egg layers compared to Isa brown and Nera black. It is therefore recommended that farmers should avoid the use of Noiler strain for commercial egg production

\section{References}

Ayorinde, K. L., Joseph J. K., Adewale, O. E. and Ayandibu, I. J. 1999. Growth, laying performance and egg quality traits of 'NAPRI commercial layers' on deep litter and in cages. Tropical Journal of Animal Science. 1 (1). Pages 147155

Beutler, A. 2007. Introduction to poultry production in Saskatchewan, University of Saskatchewan, Saskatoon, Saskatchewan, S7N $5 \quad$ A 8 http://www.agriculture.gov.sk.ca/ Introduction_Poultry Production Saskatchewan Accessed: November 18, 2009

Bright, A. and Joret, A. D. 2012. Laying hens go undercover to improve production, Veterinary Record, Vol. 170, 228.

Deeb, N. and Lamont, S. J. 2002. Genetic architecture of growth and body composition in unique chicken populations. J. Heredity. Vol. 93: pp. 107-118.

FAWC 2007 Opinion on enriched cages for $1 \mathrm{a} \mathrm{y} \mathrm{i} \mathrm{n} \mathrm{g} \mathrm{h} \mathrm{e} \mathrm{n} \mathrm{s}$ http://www.fawc.org.uk/pdf/ 


\section{Mosobalaje and Adedoyin}

Hocking P.M., Bain M., Channing C.E., Fleming R, and Wilson S. 2003. genetic variation for e $g \quad g$ production, egg quality and bone strength in selected and traditional breeds of laying fowl. Br Poult Sci 44:365-373.

Hockings, D.M. 1987. Nutritional interactions and reproduction in bird. Proc. of the Nutrition Society. 46: 217-225.

Hossain, M. S. 1992. Comparative study on egg production and feed efficiency of different breed of poultry under intensive and rural conditions in Bangladesh. Livestock Research for Rural Development. 4(3) December 1992.

Imouokhome, J. I. and Ojogho, O. 2012, Comparative performance of Bovans Nera (Rhoda black) and other commercial pullet strains. Notulae. Scientia. Biologicae. Vol.4(3) (Foreign).

Kassandra, S. 2015. Isa brown; a comprehensive guide. Backyard $\mathrm{ch} \mathrm{i} \mathrm{cke} \mathrm{n} \mathrm{C} \mathrm{o} \mathrm{o} \mathrm{p.} \mathrm{W} \mathrm{w} \mathrm{w} \mathrm{.}$ Backysrdchickencoop.com.au. retrieved on June 28, 2019.

Leeson, S. and Summer, J. D. 1981. Effect of rearing diet on performance of early maturing pullet. Can. J.Animal Sci. 61:743-749.

Leeson, S. and Summer, J. D. 2005. Commercial poultry nutrition. $3^{\text {rd }}$ Edition, University Books, Guelph, Ontario Canada.

Mitchell, M. A. and Kettlewell, P. J. 2004. Transport of chicks, pullets and spent hens. In: Welfare of the Laying Hen, G.C. Perry. (ed.), CABI Publishing, Oxford Shire, UK, pp 361 - 372

Olawumi, S. O.2007. Genotype and season interaction effects on reproductive performance of two breeds of layers in humid zone in Nigeria.
Appl Tropical Agric 12:78-82.

Olawumi, S. O., Ogunlade, J. T., Oseni, S. O. and Akinokun, J. O. 2006. egg quality

characteristics of two breeds of layer breeders in South West, Nigeria.Proc. 11 Ann. Conference of Animal Science of Nigeria (ASAN). Sept. 18-21, 2006. Institute of Agricultural Research and Training, Ibadan, Nigeria. pp: 249-250.

Olawumi, S. O. and Dudusola, I. 2011. Assessment of long-term production traits of three breeds of exotic commercial layers in the derived savannah zone of Nigeria. Journal of Applied and Natural Science. 3(1): 20-24.

Oluyemi, J. A. and Robert, F.A. 2000. Poultry production in warm wet climate. Macmillian publishers, London and Basingstoke $197 \mathrm{pp}$.

Rose, S. P. 1997. Principles of poultry science. CAB International Wallington Ford, U. K. Sciences Department, 3300 Litton Reaves Hall, VA Tech, Blacksburg, VA.

Sandilands, V., Hocking, P. M., Tolkamp, B. J. and D'Eath, R. B. 2012 The use of conditioned place preference to determine broiler preferences for quantitative or qualitative dietary restriction. British Poultry Science, 53:3, pp. 291-306. ISSN 0007$\begin{array}{lllll}1 & 6 & 6 & 8\end{array}$. http://hdl.handle.net/11262/8212

Shingleton, D. 2004 Disease control. In: Welfare of the laying hen, G.C. Perry. (ed.), CABI Publishing, Oxfordshire, UK, pp 279-282

www.kuroilerchicken.com. Kuroiler the village miracle bird. Retrieved December, 2020

Yakubu, D., Ogah, M. and Barde, R. E. 2008. Productivity and egg quality characteristics of free range naked 
Point of lay performance of three strains of chicken

neck and normal feathered Nigerian Indigenous Chickens International Journal of Poultry Science 7 (6): 579-585.

Received: $10^{\text {th }}$ May, 2021

Accepted: $15^{\text {th }}$ August, 2021 